\title{
Efficacy and Duration of Trunk-Injected Imidacloprid in the Management of Hemlock Woolly Adelgid (Adelges tsugae)
}

\author{
Joseph J. Doccola, Eric J. Bristol, Samantha D. Sifleet, Joseph Lojko, and Peter M. Wild
}

\begin{abstract}
Hemlock woolly adelgid (Adelges tsugae) (HWA) is an introduced piercing, sucking insect that affects hemlocks (Tsuga spp.) by extracting carbohydrates from the xylem ray parenchyma cells. Left untreated, HWA will result in reduced shoot growth, branch dieback, and ultimately tree death. In this study, the insecticide IMA-jet (5\% imidacloprid w/w) was applied by trunk microinjection with the Arborjet Tree I.V. using the VIPER method. Sixteen randomly selected HWAinfested hemlocks were treated in 2002 and 2003 and eight trees were selected as untreated controls. Eight infested branch samples per tree were cut each year (2003, 2004, and 2005) and assessed. Four parameters were used to assess the efficacy and duration of treatments. These were percent HWA mortality, total and live HWA per linear centimeter shoot growth, and current-year shoot growth. The eastern hemlock (T. canadensis) in this study had high initial HWA pressure. In the 3 years of the study, winter low temperatures were insufficient to cause an appreciable or sustainable reduction in infestation levels. In the controls, HWA increased and hemlock growth decreased. Treatment with stem-injected imidacloprid did not provide a quick knockdown of the HWA; rather, it required time (i.e., at least 1 year). In the year after a second treatment, we observed sufficiently high HWA mortality for hemlock to resume growth. We have a high degree of confidence that a repeat treatment increased the levels of imidacloprid for the duration of efficacy observed. We recommend a $2 \times$ dosage (e.g., for trees in the 30 to $59 \mathrm{~cm}$ [12 to $23.6 \mathrm{in}$ ] size class, increase from $0.08 \mathrm{~g}$ A.I. to $0.16 \mathrm{gm}$ A.I./cm trunk diameter at breast height $[\mathrm{dbh}]$ ) for an increased level of efficacy to extend the injection interval (to once every 2 years) and to limit the number of wounds a tree receives to centimeters $\mathrm{dbh} / 5(\mathrm{dbh} \mathrm{in} / 2)$. The new rate recommendations are reflected on the IMA-jet label amended in 2006. These results demonstrate that hemlock with high HWA pressure can be successfully treated using IMA-jet and the Arborjet Tree I.V. system.
\end{abstract}

Key Words. Arborplug; hemlock; hemlock woolly adelgid; IMA-jet; imidacloprid; micro-infusion; plant health; systemic injection; Tree I.V.; trunk injection; VIPER; wound response.

Hemlock woolly adelgid (Adelges tsugae) (HWA) is an introduced piercing, sucking insect that negatively affects hemlocks (Tsuga canadensis, T. caroliniana) by extracting carbohydrates from the xylem ray parenchyma cells (McClure 1991). Tree health is dependent on these carbohydrates for growth, maintenance, reproduction, defense, and storage (Shigo 1991). Eastern hemlock (T. canadensis) shows a marked sensitivity to HWA infestation. McClure (1991) has reported that as few as four HWAs/ $20 \mathrm{~mm}^{2}$ of branch seriously affected growth in forest stands. The observable changes include reduction of shoot growth (stunting), chlorosis (yellowing), and shedding (needle loss), all of which are symptomatic of suppressed hemlock health. Dieback in hemlock may occur within 2 years of HWA infestation, first affecting the lower canopy and then progressing upward in the tree (McClure et al. 1996). Hemlock mortality can occur in as little as 4 years of initial HWA infestation (McClure 1991).
The three treatment options recommended for managing HWA infestations are foliar sprays, soil application, and trunk injection. Spray applications of horticultural oil, insecticidal soap, or petrochemical insecticides are used for treatment of HWA but depend on thorough foliar coverage, which is difficult in tall trees (McClure 1998) and subject to aerial drift. Soil-injected insecticides eliminate the problem of drift inherent in foliar applications, but leaching in the soil profile is of concern in sensitive sites (Jenkins 1994; Rômulo et al. 2004). Trunk injection is an environmentally sensitive, effective, and long-lasting approach to pesticide application (Grosman et al. 2002; Potter et al. 2002; Young 2002; Shearer et al. 2004).

Although effective, the wounds created when trees are injected are a concern to the arborist (Shigo 1977, 1979, 1984; Pearce 2000). Trees do tolerate some wounding; however, the more frequently injections are made, the more apt the con- 
cern. For example, a number of microinjection labels allow or recommend repeated annual treatments. We believe injections should be applied when indicated; monitoring is a critical component in that decision-making process. Increasing the application interval to beyond an annual treatment, if possible, is a clear advantage.

Wound response to stem injection is dependent on a number of factors, including the tree species, the time of year, the method of injection, and the chemical formulation. The pattern of Compartmentalization of Decay in Trees (CODIT) (Shigo 1977, 1979) responses are similar in hardwoods and conifers; however, there are qualitative differences, because their anatomy and physiology are quite distinct. It has been our observation that eastern hemlock is less susceptible to injection wound infections compared with the ring porous hardwoods (e.g., American elm [Ulmus Americana] is highly susceptible to bacterial wetwood infection). Wound closure, on the other hand, occurs at a slower rate in hemlock than in American elm. This is related to tree vigor and species (Neely 1988). The time of year may influence wound response. Wound closure is dependent on growth and differentiation of callus tissue (Shigo 1989) and is limited by winter dormancy. In beech and oak, wound closure was reduced when injuries were made in December and February compared with wounds made in April or October (Dujesiefken et al. 2005). Hudler and Jensen-Tracy (2002), however, reported no significant differences in wounds inflicted mid-June or early November in eastern white pine (Pinus strobus). These data suggest that spring or fall injection wounds are less injurious than those applied during winter dormancy. Even so, the size (width $\times$ depth) and frequency of wounds also play a role in tree response to wounding.

Systemic distribution of trunk injected chemicals into the canopy of conifers requires multiple injections sites (Larson et al. 1994). Recommendations for injection into hardwood trees follow this same pattern of distributing the application sites around the bole of the tree. The number of injection sites, however, varies with the method from a high of 3.75 application sites per $\mathrm{cm}$ trunk diameter at breast height (dbh) (1.5 application sites/dbh in) for Macro-infusion applications (Rainbow Tree, Minneapolis, MN) to the J.J. Mauget Company (Arcadia, CA) microinjection recommendation of centimeters $\mathrm{dbh} / 5(\mathrm{dbh} \mathrm{in} / 2)$. The number of application sites and distribution of the injected chemical are directly related. The variation in the number recommended, in practice, is related to the volume and frequency of application. For example, high-volume Macro-infusion applications are made less frequently (i.e., once every 3 years) compared with very-lowvolume microinjection applications, which may be repeated annually. Although movement of sap in the stem is generally upward (i.e., straight sectoral ascent), there is considerable variation in the path of water movement across species. Spiral ascent occurs in a number of species, including conifer xylem
(Kozlowski and Winget 1963). Furthermore, conifers and diffuse porous hardwoods tend to use a larger proportion of sapwood than the ring porous hardwoods for water movement. In a study using dye to assess canopy distribution in black cherry (Prunus serotina), a diffuse porous hardwood, injection applications were made comparing centimeters $\mathrm{dbh} / 5$ (dbh in/2) to $\mathrm{cm} \mathrm{dbh} / 10$ (dbh in/4) (Doccola and McComiskey, unpublished data). The mean distribution of dye in the tree canopies were $92 \%$ and $80 \%$, respectively. We made the assumption that injections into hemlock will distribute at least as well as that observed in the dye study. In this study, we applied the centimeters $\mathrm{dbh} / 10$ formula, which is half the number of application sites used in microinjection applications to limit the wounds made. The injection sites were located around the lower bole of the tree in tissues immediately superior to the trunk flare.

Tattar et al. (1998), Webb et al. (2003), and Doccola et al. $(2002,2003)$ have demonstrated that trunk-injected imidacloprid (1-[(6-chloro-3-pyridinyl) methyl]-N-nitro-2-imidazolidinimine), a nicotinoid insecticide, is effective for control of HWA. In these studies, the amount of active ingredient (A.I.) applied using IMICIDE (J.J. Mauget Company) was $0.06 \mathrm{gm}$ A.I./cm dbh (0.15 g A.I./dbh in) for small- and large-diameter trees. In this study, treatments were applied in early to midOctober using IMA-jet insecticide (Arborjet, Inc., Woburn, MA), a $5 \%$ by weight liquid formulation of imidacloprid. The amount of A.I. administered using the IMA-jet was commensurate with tree size class and ranged from 0.04 to $0.12 \mathrm{~g}$ A.I./cm dbh (0.1 to $0.3 \mathrm{~g}$ A.I./dbh in). The mean dosage applied was $0.08 \mathrm{~g}$ A.I./cm dbh, comparable to the IMICIDE dosage. The purpose of this study was to assess IMA-jet insecticide efficacy after each of two fall treatments against HWA (i.e., $1 \times$ dose $\times 2$ treatments) and whether these outcomes suggest increasing the dosage to extend the application interval to once every 2 years (i.e., $2 \times$ dose $\times 1$ treatment). The formulation was applied directly to the xylem through a shallow drill hole (Martin and Sydnor 1987; Tattar and Tattar 1999) and of sufficient depth (15 mm [0.6 in]) to minimize exposure of the secondary vascular tissues surrounding the application site to the formulation chemistry. The latter was an important consideration to minimize injury (i.e., from chemical phytotoxicity to the cambium and phloem tissue surrounding the injection site). The application of low pressure ensured that the entire dosage was delivered.

The timing of treatment was based on two factors, which were tree uptake and insect susceptibility. Coniferous species are more difficult to inject than hardwoods (Sanchez-Zamora and Fernandez-Escobar 2004) as a result of their vascular anatomy and response to environmental conditions. In hemlock, the rate of uptake is limited by tracheid diameter (Tyree and Ewers 1991; Lancashire and Ennos, 2002; Mayr et al. 2003). Xylem flow depends on evapotranspirational loss 
(Brodribb and Felid 2000) from needle stomata. Guard cells close in response to atmospheric vapor pressure deficit to maintain needle turgor (Oren et al. 1999; Baker et al. 2001). Injection rate is likewise commensurate with xylem sap flow and dependent on conditions favoring evapotranspiration (Schulze et al. 1985). Temperature plays a significant role, affecting atmospheric vapor deficit and soil moisture availability. Systemic movement of stem-injected dyes in trees occurs when soil temperatures reach a minimum $5^{\circ} \mathrm{C}\left(41^{\circ} \mathrm{F}\right)$ (Tattar and Tattar 1999). These temperatures are more likely to be met in April through November in the northeastern United States (see Figure 1). The environmental conditions that favor injection uptake in hemlock are moderate soil and ambient temperatures, high relative humidity, and available soil moisture.

Fall treatments also coordinate with HWA life cycle and susceptibility. HWA is most susceptible to exposure to an injected systemic insecticide when it is actively feeding. HWA breaks its summer aestivation in October in the northeastern United States and resumes feeding activity. This sistens generation will continue to develop through April (Ward et al. 2004). Spring treatments are also possible because the progrediens generation, which occurs May through June, may be targeted (Ward et al. 2004). Fall assessments of HWA were conducted on the current year's growth and before the onset of very low temperatures to minimize the effects of winter mortality (Costa et al. 2004).

\section{MATERIALS AND METHODS}

\section{The Tree-Device Interface}

The Tree I.V. and the VIPER method (Arborjet, Inc.) were the devices selected to deliver the treatments (Figure 2). The Tree I.V. uses low pressure (35 PSI) to aid in the delivery of formulation. Low pressure ensures that the contents of the 1-L bottle empty completely and that flow is commensurate with hydraulic movement in the xylem. The VIPER method refers to the injection interface, that is, the Tree I.V. needle and Arborplug (Arborjet, Inc.) (Figure 3). The Arborplug is a plastic device constructed with a guide cap, three anchoring barbs, an internal self-sealing septum, and infusion legs. It is designed to deliver formulation directly into the most current (12 to $15 \mathrm{~mm}$ [0.48 to $0.6 \mathrm{in}]$ ) xylem and to prevent backflow. In this study, \#4 Arborplugs $(15 \mathrm{~mm} 1 \times 9 \mathrm{~mm}$ w [0.6 in $1 \times$ 0.36 in w]) were used. A clean, sharp $9 \mathrm{~mm}$ (0.36 in) brad point bit was used to drill into the sapwood. Without applying pressure, the drill bit cuts easily through the lower-density phloem tissues; it will not cut into the denser xylem until pressure is applied. Once at the xylem-phloem interface, the bit cuts to the 12 to $15 \mathrm{~mm}$ ( 0.48 to 0.6 in) depth with a quick push in and pull out. The Arborplug is inserted using a set tool and mallet. The Tree I.V. needle, when inserted, pierces the septum to deliver the formulation. The injected liquid moves around the infusion legs and into the vascular tissue.

\section{The Method and Rate Determination}

Eastern hemlock (Tsuga canadensis) selected in this study had high initial HWA pressures on both the treated and control trees. Sixteen HWA-infested hemlocks in Winchester, Massachusetts, were selected at random for two consecutive fall treatments (i.e., 2002 and 2003). IMA-jet insecticide (5\% imidacloprid $\mathrm{w} / \mathrm{w}$ ) was applied at the label rates based on tree size class with the Arborjet Tree I.V. and VIPER method. Tree diameter at breast height (dbh, $135 \mathrm{~cm}$ [54 in] from soil level) was used as a basis to determine dosage. The tree size classes were 5 to 29,30 to 59 , and 60 to $89 \mathrm{~cm}$ (2 to 11.6, 12 to 23.6 , and 24 to 35.6 in), and the HWA label rates for each class were $0.8,1.6$, and $2.4 \mathrm{~mL}$ per centimeter $\mathrm{dbh}(2,4$, and

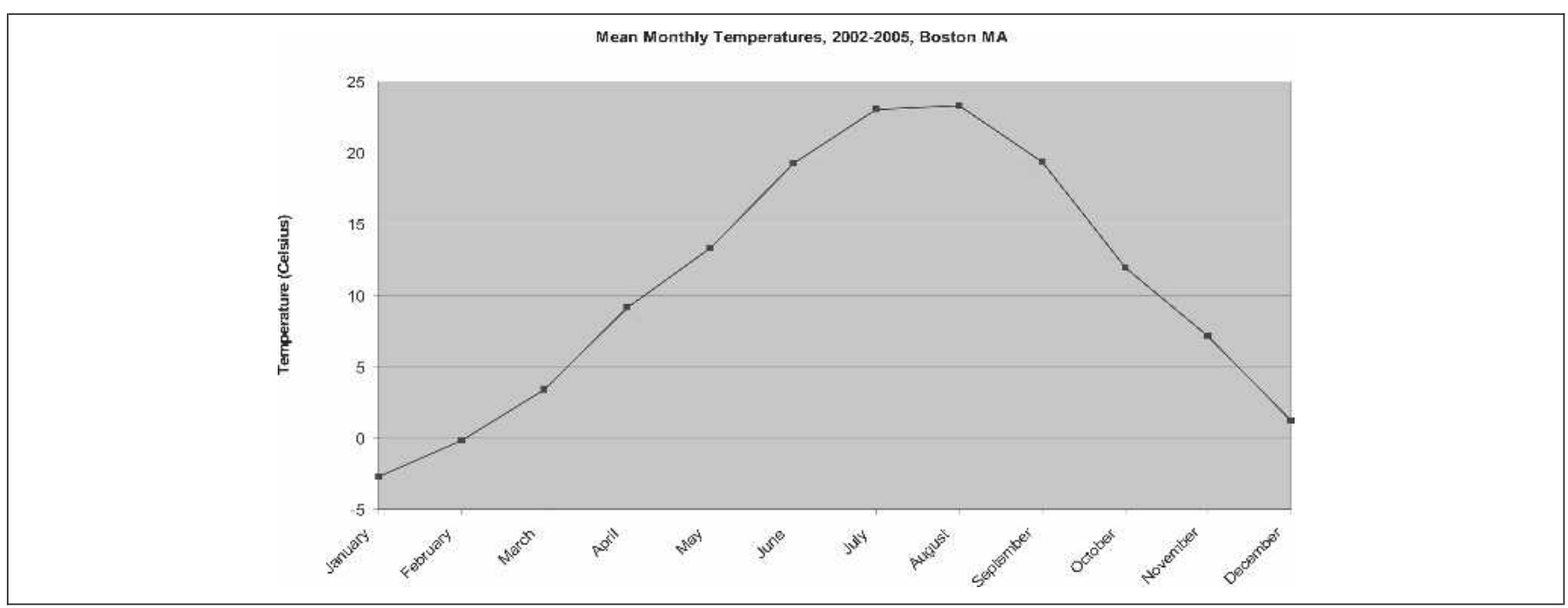

Figure 1. Mean monthly temperature in degrees Celsius 2002 through 2005 in Boston, Massachusetts. 


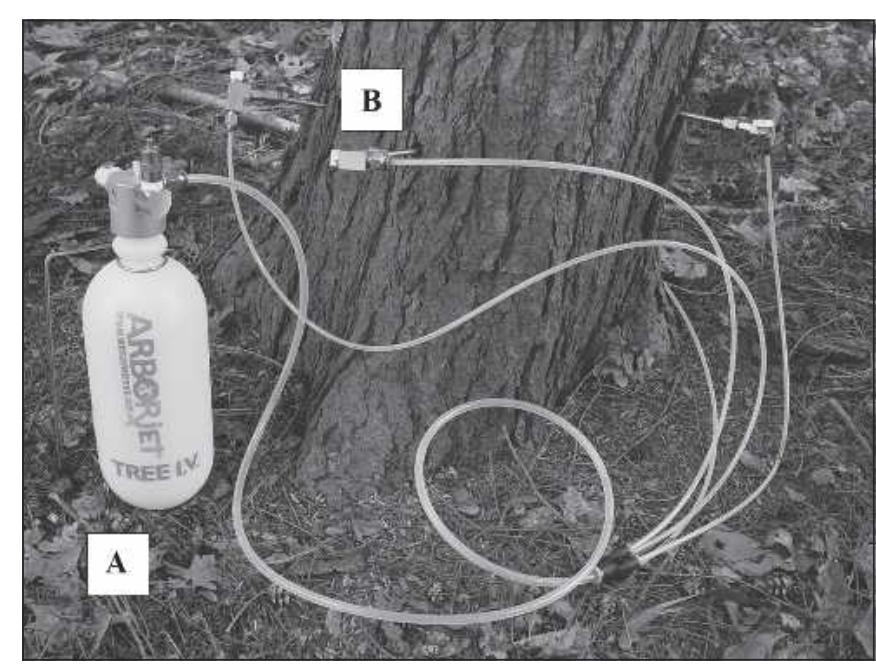

Figure 2. The Arborjet Tree I.V. (A) used to deliver treatments in this study set up with the VIPER needles (B). The system is pressurized to deliver liquid formulation into the sapwood.

$6 \mathrm{~mL}$ per inch $\mathrm{dbh}$ ), respectively. Dosage was determined by multiplying tree diameter with the prescribed rate for that size class. For example, a $35 \mathrm{~cm}$ dbh (14 in dbh) tree requires 1.6

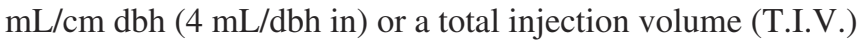
of $56 \mathrm{~mL}(1.68 \mathrm{fl} \mathrm{oz})$ of IMA-jet. The measured fluid amount is poured into the Tree I.V. bottle. The working liquid capacity of the Tree I.V. is $0.5 \mathrm{~L}(1.05 \mathrm{pt})$. Standard with the Tree I.V. are four needle injection tips connected to a branch manifold with chemically resistant tubing. The Tree I.V. is pressurized with a hand pump. Once primed, the VIPER needles are inserted into the Arborplugs to begin the injection.

Mean dbh of microinjected hemlock was $35 \mathrm{~cm}$ (14 in dbh) with a range of 17 to $65 \mathrm{~cm}$ (6.8 to $26 \mathrm{in} \mathrm{dbh})$ and mean $\mathrm{dbh}$ of control trees was $24 \mathrm{~cm}$ (9.6 in dbh) with a range of 12 to $32 \mathrm{~cm}$ (4.8 to $12.8 \mathrm{in} \mathrm{dbh).} \mathrm{Mean} \mathrm{dosage} \mathrm{applied} \mathrm{was} 1.6 \mathrm{~mL}$ per centimeter dbh ( $4 \mathrm{~mL} / \mathrm{dbh}$ in) delivering $0.08 \mathrm{~g}$ A.I./cm dbh (0.2 g A.I./dbh in) per treatment. Table 1 outlines the treatment and assessment schedule used in this study.

\section{Sampling Procedure}

Twig samples were collected in Fall 2003, 2004, and 2005 from 16 treated hemlocks and eight nontreated control trees. In all 3 years, samples were collected for evaluation from late October to late December when the HWA are active. In the Fall 2003, samples were collected after the second injection treatment. Infested branch samples were selected for HWA mortality assessment. Eight branch samples from each tree (two from each quadrant) were cut between 45 to $60 \mathrm{~cm}(18$ to $24 \mathrm{in})$ in length, bagged, labeled, refrigerated $\left(7.2^{\circ} \mathrm{C}\right.$ $\left[44.96^{\circ} \mathrm{F}\right]$ and $60 \%$ relative humidity), and evaluated within

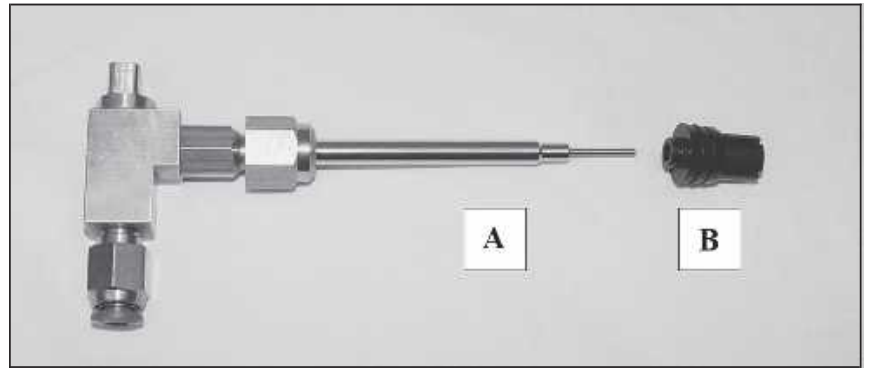

Figure 3. The VIPER method uses the VIPER needle (A) and \#4 Arborplug (B). A brass stem valve controls liquid flow at each needle. The Arborplug is placed into the sapwood and remains in the tree after treatment. The VIPER needle pierces an internal septum in the Arborplug to deliver formulation. The VIPER method is designed to deliver the formulation to the xylem, to prevent backflow, and to provide a surface for woundwood development.

$48 \mathrm{hr}$. Samples were taken using a number 180 ARS longreach pruner with a $3 \mathrm{~m}(9.9 \mathrm{ft})$ extension and an extension pull pruner capable of reaching $9 \mathrm{~m}(29.7 \mathrm{ft})$. In the laboratory, branch samples with dieback (i.e., with no current year shoot growth) were discarded. Discarding samples without growth helped to control for density-dependent effects (McClure 1991), for winter low temperature effects on HWA survival, and to minimize for poor insecticide translocation into suppressed branches. In 2003, we assessed one terminal with new shoot growth per branch collected. In the subsequent evaluations, we increased the sample size by assessing five branchlets with new shoot growth taken from each of the eight branch terminals.

\section{Hemlock Woolly Adelgid and Hemlock Evaluation}

Only sistens nymphs and adults on current-year twig growth were evaluated. Microscopic examination was used to determine HWA mortality. Live HWA are light in color, plump, demonstrate appendage response, and develop fresh (white) wool. Dead HWA are dark in color, desiccated, nonresponsive, and have little (gray, matted) or no wool. Total HWA is the number of individuals counted whether alive or dead. It

Table 1. Treatment dates, mean dose, frequency of application, and assessment schedule used in this study.

\begin{tabular}{lll}
\hline Date & $\begin{array}{l}\text { Mean dose of IMA-jet } \\
(35 \mathrm{~cm}[14 \mathrm{in}] \mathrm{tree})\end{array}$ & $\begin{array}{l}\text { Assessment } \\
\text { schedule }\end{array}$ \\
\hline Fall 2002 & $56 \mathrm{~mL}(1.68 \mathrm{fl} \mathrm{oz})$ & NA \\
Fall 2003 & $56 \mathrm{~mL}(1.68 \mathrm{fl} \mathrm{oz})$ & Year 1 \\
Fall 2004 & $0 \mathrm{~mL}$ & Year 2 \\
Fall 2005 & $0 \mathrm{~mL}$ & Year 3 \\
\hline
\end{tabular}


should be noted that dead HWA remain on the twigs. IMA-jet treatment efficacy was evaluated on the basis of four measurements, including percent HWA mortality, live and total HWA/linear centimeter shoot growth, and current-year linear shoot growth. Percent HWA mortality is derived using the equation, [(dead HWA/total HWA $) \times 100]$, as determined by microscopic inspection. Current-year shoot growth is the measurement of the length of the new growth increment of each branchlet for that year. Total and live HWA/linear centimeter shoot growth is the number of total or living HWA found on the current growth increment divided by the length $(\mathrm{cm})$ of that growth increment. Total HWA/linear centimeter shoot growth is reported as this correlates to McClure's observations (1991).

\section{Climate Data}

Costa et al. (2004) report $-25^{\circ} \mathrm{C}\left(-13^{\circ} \mathrm{F}\right)$ as the point of initiation of significant HWA mortality and $-30^{\circ} \mathrm{C}\left(-22^{\circ} \mathrm{F}\right)$ and $-35^{\circ} \mathrm{C}\left(-31^{\circ} \mathrm{F}\right)$ as the lower lethal threshold temperatures of no HWA survival. The lowest temperatures recorded for the period of HWA evaluations in this study was $-14^{\circ} \mathrm{C}$ $\left(6.8^{\circ} \mathrm{F}\right)$ on 20 and 21 December 2004, well above the reported transitional point and lethal thresholds. The mean ambient temperature for the December months was $1.2^{\circ} \mathrm{C}\left(34.2^{\circ} \mathrm{F}\right)$. Low temperatures would not have had a significant impact on evaluation of HWA mortality. Figure 1 presents the mean monthly temperatures for the study and evaluation periods. These data were summarized from the National Oceanographic and Atmospheric Administration web site (www. weather.gov/climate).

\section{RESULTS}

Four parameters were tested each year (2003, 2004, and 2005) with a Student's t-test at $P<0.05$ using Minitab 14 statistical analysis software (Minitab Inc., State College, PA). The 95\% confidence intervals (CIs) were also calculated with Minitab 14. Mean values were used to compare IMA-jettreated hemlock and control hemlock sample populations. The four parameters tested were percent HWA mortality, total and live HWA per linear centimeter shoot growth, and current year shoot growth. The percent HWA mortality data were transformed to arcsine values to ensure the data are normally distributed. The arcsine values were assessed for significance using a Student's t-test, and the mean arcsine values were then converted back to percent HWA mortality and reported in Table 2.

\section{Percent Hemlock Woolly Adelgid Mortality}

Each year of evaluation, the number of dead HWA on new growth was determined. Total sample populations and means for each year are presented in Table 2. The mean percent HWA mortality for IMA-jet treated hemlock increased from 91.4 to 98.5 from 2003 to 2005 . The percent HWA mortality for controls varied from year to year with a high of 53.3 to a low of 20.5. Student's t-test indicated significant differences between IMA-jet and control samples each year after treatment in 2003. These results suggest that we can expect $10.8 \%$ to $41.2 \%, 52.0 \%$ to $60.3 \%$, and $34.1 \%$ to $45.4 \%$ greater HWA mortality in treatments than in controls for 2003, 2004, and 2005 , respectively, at the $95 \%$ CI. The HWA mortality observed affects the subsequent year's growth response (e.g., $91.4 \%$ mortality in 2003 resulted in $5.79 \mathrm{~cm}$ growth in 2004). This needs to be kept in mind when assessing treatment response.

\section{Hemlock Woolly Adelgid per Linear Shoot Growth}

Each year, the number of total and live HWA per linear centimeter shoot growth was determined. Sample population numbers and mean total and live HWA/linear centimeter shoot growth are presented in Table 2. The mean total HWA/ linear centimeter shoot growth for IMA-jet treated hemlock were $2.57,0.59$, and $0.20(6.43,1.48$, and 0.50 total HWA/ linear inch) for 2003, 2004, and 2005, respectively. The mean total HWA/linear cm shoot growth for controls were 3.46, 3.04 , and $4.91(8.65,7.60$, and 12.28 total HWA/linear inch) for 2003, 2004, and 2005, respectively. Significant differences $(P=0.000)$ were found between IMA-jet treatments and controls in the years 2004 and 2005.

The mean numbers of live HWA per linear centimeter for IMA-jet treated hemlock were $0.59,0.06$, and $0.02(1.48$,

Table 2. Mean results $(2003,2004$, and 2005$)$ for percent hemlock woolly adelgid (HWA) mortality, total and live and HWA/linear centimeter shoot growth, and new linear shoot growth².

\begin{tabular}{|c|c|c|c|c|c|c|c|c|c|c|c|c|}
\hline & \multicolumn{4}{|c|}{2003} & \multicolumn{4}{|c|}{2004} & \multicolumn{4}{|c|}{2005} \\
\hline & (n) & IMA-jet & (n) & Control & (n) & IMA-jet & (n) & Control & (n) & IMA-jet & (n) & Control \\
\hline Percent HWA mortality (transformed) & 78 & $91.4 \% \mathrm{a}^{\mathrm{y}}$ & 17 & $53.3 \% \mathrm{~b}$ & 154 & $98.5 \%$ a & 238 & $20.5 \% \mathrm{~b}$ & 33 & $98.5 \%$ a & 129 & $46.8 \% \mathrm{~b}$ \\
\hline Total HWA/cm & 108 & $2.57 \mathrm{a}$ & 19 & $3.46 \mathrm{a}$ & 549 & $0.59 \mathrm{a}$ & 281 & $3.04 \mathrm{~b}$ & 185 & $0.20 \mathrm{a}$ & 134 & $4.91 \mathrm{~b}$ \\
\hline Live HWA/cm & 108 & $0.59 \mathrm{a}$ & 19 & $1.92 \mathrm{a}$ & 549 & $0.06 \mathrm{a}$ & 281 & $2.16 \mathrm{~b}$ & 185 & $0.02 \mathrm{a}$ & 134 & $2.76 \mathrm{~b}$ \\
\hline New linear shoot growth $(\mathrm{cm})$ & 108 & $6.03 \mathrm{a}$ & 19 & $5.71 \mathrm{a}$ & 549 & $5.79 \mathrm{a}$ & 281 & $4.78 \mathrm{~b}$ & 185 & $6.26 \mathrm{a}$ & 134 & $5.48 \mathrm{~b}$ \\
\hline
\end{tabular}

${ }^{\mathrm{z} B r a n c h l e t s ~ w i t h ~ n o ~ H W A ~ w e r e ~ d i s c a r d e d ~ f o r ~ p e r c e n t ~ H W A ~ m o r t a l i t y . ~}$

${ }^{\mathrm{y}}$ Mean values in the same year and parameter followed by a different letter are significantly different according to a Student's t-test.

$\mathrm{n}=$ number of data points use for statistical analysis in the specified treatment and year. 
0.15, and 0.05 live HWA/linear inch) for 2003, 2004, and 2005 , respectively. In the treatments, we observed a decrease in HWA pressure over time. The live HWA per linear centimeter for control samples were 1.92, 2.16, and 2.76 (4.8, 5.4, and 6.9 live HWA/linear inch) for 2003, 2004, and 2005, respectively. In the controls, we observed increasing HWA pressure over the 3 year study. A Student's t-test determined significant differences between IMA-jet and control samples in 2004 and 2005. The results for 2004 and 2005 indicate that one can expect a difference of 1.84 to 2.37 and 2.23 to 3.26 live HWA/linear centimeter (4.60 to 5.93 and 5.58 to 8.15 live HWA/linear inch) between treatments and controls, respectively, at a $95 \%$ CI. The 2003 sample populations for live HWA/linear centimeter on IMA-jet and control trees was not significant with $P=0.066$.

\section{New Linear Shoot Growth}

Each year, new hemlock shoot growth was determined for each sample. The current-year shoot growth is best correlated with the previous year's treatment. The mean length of new growth for IMA-jet-treated hemlock was 6.03, 5.79, and 6.26 $\mathrm{cm}(2.41,2.32$, and $2.50 \mathrm{in})$ for 2003,2004 , and 2005, respectively. The mean length of new growth for control samples was 5.71, 4.78, and $5.48 \mathrm{~cm}(2.28,1.91$, and $2.19 \mathrm{in})$ for the same years, respectively. A Student's t-test indicated there are significant differences between IMA-jet and control samples for the years 2004 and $2005(P=0.000$ and $P=$ $0.025)$. The results in the two most recent evaluations reflect from 0.53 to $1.48 \mathrm{~cm}(0.21$ and 0.59 in) and 0.10 to $1.47 \mathrm{~cm}$ ( 0.04 to 0.59 in) more growth in the treatments, respectively, at the $95 \%$ CI.

The distributions of hemlock shoot growth with $<4$ total, and 4 total or $>$, and $<2$ live, 2 live or $>$ HWA/linear $\mathrm{cm}$ are plotted in Figures 4 and 5. Both followed a normal distribution. These data reflect the entire sample population (1277 samples), including IMA-jet-treated and control samples.

Figure 4 presents the difference $(P=0.000)$ between the distribution of shoot growth in samples with less than four total HWA/linear centimeter shoot growth $(6.02 \mathrm{~cm}$ [2.41 in]) versus four or greater total HWA/linear centimeter shoot growth $(4.41 \mathrm{~cm}[1.76 \mathrm{in}])$. That is to say, we can expect from 2.25 to $2.97 \mathrm{~cm}$ ( 0.90 to $1.19 \mathrm{in})$ more growth when the total HWA/linear centimeter is less than 4 at a $95 \%$ CI. Figure 5 presents a statistically significant difference $(P=0.000)$ between distribution of hemlock shoot growth in samples with less than two live HWA/linear centimeter (5.96 cm [2.38 in]) versus two or greater live HWA/linear $\mathrm{cm}(3.92 \mathrm{~cm}[1.57$ in]). We observe 1.66 to $2.42 \mathrm{~cm}$ (0.66 to $0.97 \mathrm{in})$ greater shoot growth in hemlock when live HWA/linear centimeter is less than two at the 95\% CI. Here we were interested in quantifying the live HWA pressure on hemlock growth. We used 4.0 total HWA/linear centimeter shoot growth as the number to negatively impact hemlock. This is analogous to

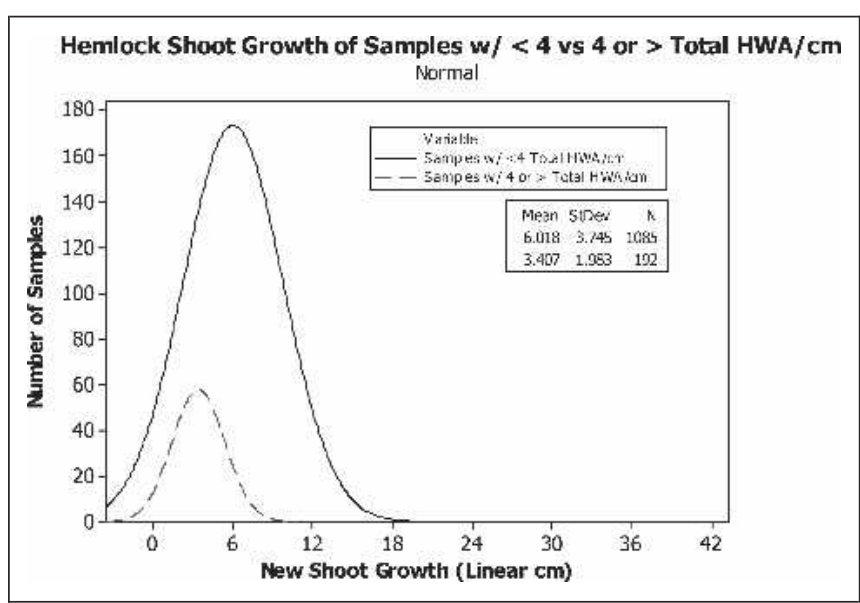

Figure 4. Shoot growth distributions in hemlock comparing less than 4 and 4 or greater total hemlock woolly adelgid (HWA)/linear centimeter. Both IMA-jet-treated and control samples were used for this analysis of HWA density and hemlock shoot growth.

2.0 live HWA/linear centimeter shoot growth when percent HWA mortality in the control trees is 50 or less. In this study, we observed from 1.92 to 2.76 live HWA/linear centimeter shoot growth in the controls throughout; these trees remained stressed.

\section{DISCUSSION}

Eastern hemlock is sensitive to HWA infestation. This sensitivity may be expressed as an inverse relationship between HWA pressures and shoot growth. McClure (1991) established four total HWA/20 $\mathrm{mm}^{2}$ of branch as the level to serious affect growth in forest stands. This is consistent with

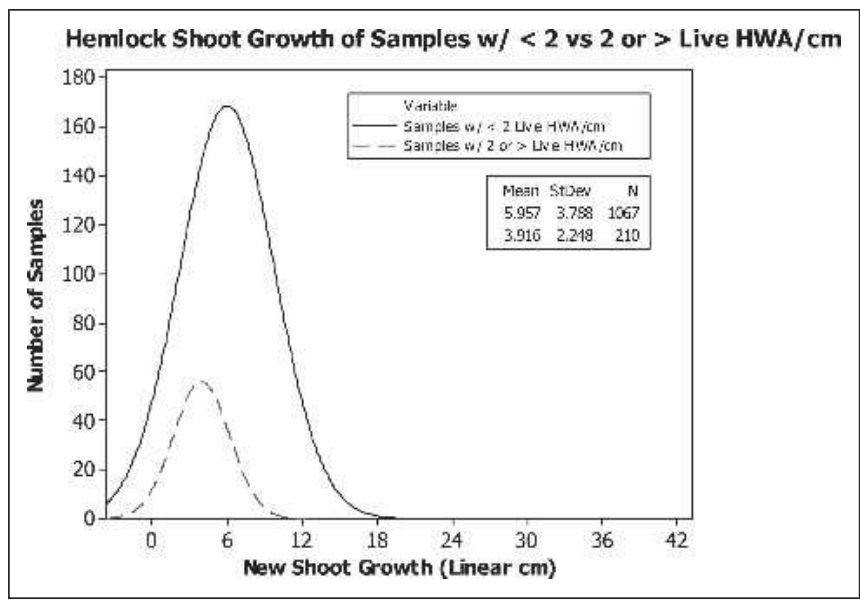

Figure 5. Shoot growth distributions in hemlock comparing less than 2 and 2 or greater live hemlock woolly adelgid (HWA)/linear centimeter. Both IMA-jet-treated and control samples were used for this analysis of HWA density and hemlock shoot growth. 
our observations in reduced shoot growth at 4.0 total HWA/ linear centimeter (10.0 total HWA/linear inch). This was one of the four parameters used to assess the efficacy of the treatments. 2.0 live HWA/linear cm (5.0 live HWA/linear inch) is comparable when HWA mortality in the controls is $50 \%$ or less.

In 2003, HWA mortality was significantly higher in the IMA-jet trees compared with the controls $(91.4 \%$ versus $53.3 \%)$. We observed a treatment effect of 2.57 total $(0.59$ live) HWA/linear centimeter compared with 3.46 total (1.92 live) in the controls, but this was not statistically significant. However, it is worth noting that in the treatment samples, HWA development was delayed (i.e., higher ratio of sistens nymphs to adults) compared with the controls. This suppression effect was most likely the result of the initial 2002 treatment applied, suggesting imidacloprid activity at a sublethal level. In each, shoot growth was not statistically different (6.03 cm [2.41 in] versus $5.71 \mathrm{~cm} \mathrm{[2.28} \mathrm{in],} \mathrm{respectively),}$ attributable to HWA pressure.

In 2004, the treatment and control populations diverged significantly and continued to do so into the Fall of 2005. HWA mortality increased to $98.5 \%$ in the IMA-jet treated trees without further treatment in 2004 and 2005. In the control trees, we observed $20.5 \%$ and $46.8 \%$ HWA mortality in the same 2 years. HWA densities also dropped significantly in the treatments to 0.59 and 0.20 total (0.06 and 0.02 live) HWA/linear centimeter compared with 3.04 and 4.91 (2.16 and 2.76 live) in the controls. The high HWA mortality observed (2004 to 2005) in the treatments had biologic significance, that is, tree health improved. In this 3 year study, we observed a mean of $2.11 \mathrm{~cm}(0.84$ in) more shoot growth in treated trees over the controls. The increase in growth results in increased photosynthesis and carbohydrate accumulation, essential to hemlock recovery. The mean HWA mortality observed in the controls in the 3 years was $40.2 \%(n=384)$, that is, $59.8 \%$ of the population survived. Winter low temperatures did not appreciably affect HWA populations. The mean live HWA/linear centimeter calculated for the controls was 2.28 , high enough to affect hemlock growth each year. These differences in hemlock response are illustrated in Figure 6.

What is interesting is the delay we observed from the time of treatment to the observed effect on HWA mortality. We observed suppressive and lethal effects of imidacloprid on HWA, but did not observe a quick knockdown when trunkapplied into hemlock. In the first analysis, samples were collected within 60 days of the second treatment application, yet our most significant results were not recorded until 365 days later. Fall analyses are very practical. HWA development proceeds for at least 90 days before the onset of extreme low winter temperatures. This provides ample time to analyze a high volume of samples. In contrast, the spring window is significantly smaller (30 days) for analyses. HWA enters a

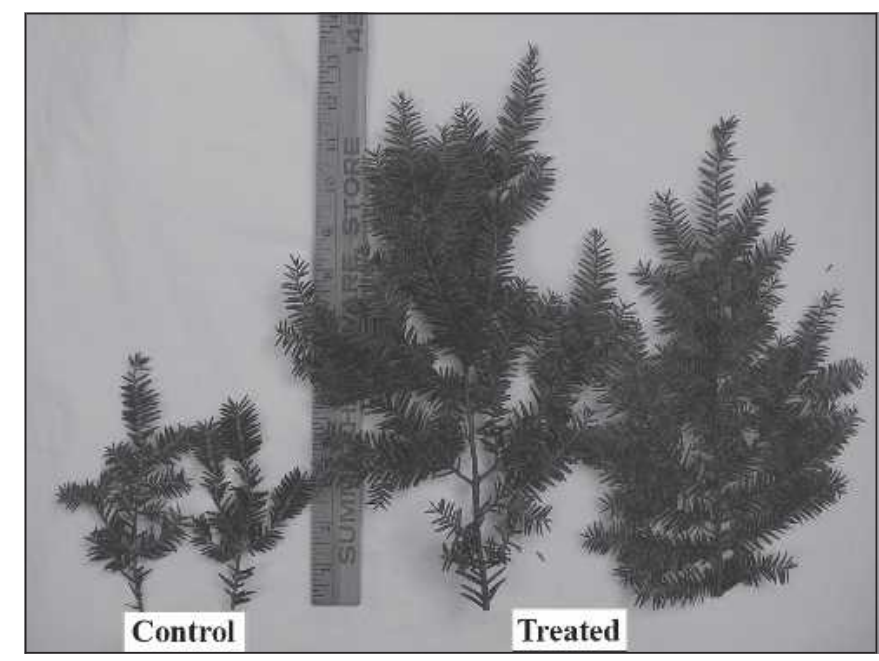

Figure 6. Hemlock samples with 3 years of growth (2003, 2004,2005 ) illustrating typical patterns of response. All hemlocks were infested with hemlock woolly adelgid (HWA) at the onset of the study. Unchecked, HWA results in reduced twig growth like in the two control branchlets (left). The treatment trees show a marked growth response when the pressure from HWA infestation is alleviated (right).

summer aestivation period, defaulting observations to the fall. Furthermore, spring observations would not have provided complete growth increments used in our analyses. We recommend fall monitoring to the arborist because time is a significant consideration. In practice, fall HWA assessment may be used to predict tree growth in the next year and to help decide whether additional treatment is needed. Another implication of slow response is to allow ample time for an observable response. The arborist needs to establish this expectation to his or her clientele.

The other possible explanations of our observations may have been the result of reduced translocation of the insecticide into suppressed twigs, poor distribution within the tree, or a low dose administered. The first explanation is unlikely, because samples without current-year growth were discarded. A more likely explanation is that the distribution of imidacloprid within the canopy may not have been uniform. We used a very low injection profile of centimeter $\mathrm{dbh} / 10$ to limit wounding. The second application increased the injection profile to centimeter $\mathrm{dbh} / 5$, having the effect of better distribution, but also increased the level of imidacloprid. Although we cannot strictly separate distribution and dose, we believe the strongest explanation (on the bases of the suppressive effects observed the first year) is that insufficient A.I. was administered.

Many microinjection labels allow for repeated treatments in part because of the limited volume in the delivery capsule (typically, 5 to $10 \mathrm{~mL}$ [0.15 to $0.30 \mathrm{fl} \mathrm{oz}]$ ). These are less 
desirable because of the increased number of wounds that result. The Tree I.V., on the other hand, has a $500 \mathrm{~mL}(15 \mathrm{fl}$ oz) liquid capacity; therefore, it is not limited to the microinjection capsule dosage or necessarily to the same frequency of application. The sensitivity of hemlock to HWA requires a high level of control as that observed after a second application of imidacloprid. In this study, the level of efficacy required and subsequent duration was achieved after a $1 \times$ dose rate $\times 2$ treatments. It is our premise that a $2 \times$ dose rate $\times 1$ treatment is preferable when treating by tree injection. A lower number of injection wounds will be an added benefit of less frequent applications. The increased volume trunk injection is what we term Micro-infusion.

\section{CONCLUSIONS}

It was our observation that left untreated, HWA on hemlock reached levels that negatively affected tree health. In the 3 years of the study, winter low temperatures were insufficient to cause an appreciable or sustainable reduction in infestation levels (highest mortality in the controls was $53.3 \%$ ). Total HWA pressure actually increased significantly (to 4.91/linear $\mathrm{cm}$ ) in the controls by year 3. Treatment with stem-injected imidacloprid did not provide a quick knockdown of the HWA population; rather, our observation was that it required time (i.e., at least 1 year). In the year after treatment, we observed significantly greater HWA mortality in the IMA-jet trees (91.4.0\%). However, we did not observe sufficient control of HWA for trees to recover until 1 year after the second treatment. We think that it is preferable to use a $2 \times$ dosage (e.g., for trees in the 30 to $59 \mathrm{~cm}$ [12 to $23.6 \mathrm{in}$ ] size class, increase from $0.08 \mathrm{~g}$ A.I. to $0.16 \mathrm{~g}$ A.I. $/ \mathrm{cm} \mathrm{dbh)} \mathrm{for} \mathrm{this} \mathrm{level} \mathrm{of}$ efficacy to limit the number of wounds a tree receives to centimeter $\mathrm{dbh} / 5$ and to extend the injection interval (to once every 2 years). This recommendation, however, does not preclude the arborist from using generally recognized Integrated Pest Management practices (I.P.M.). The practitioner should monitor insect mortality and tree health annually. It is preferable to do so in the fall to plan the subsequent year's treatments. It is our intent that this article helps to inform that process. Wound response to the Tree I.V. and VIPER injection method is currently being studied. The new rate recommendations are reflected on the IMA-jet label amended in 2006. These results demonstrate that hemlock with high HWA pressure can be successfully treated using IMA-jet and the Arborjet Tree I.V. system.

\section{LITERATURE CITED}

Baker, N.R., K. Oxborough, T. Lawson, and J.I.L. Morison. 2001. High resolution imaging of photosynthetic activities of tissues, cells and chloroplasts in leaves. Journal of Experimental Botany, Oxford University Press 52:615-621.

Brodribb, T.J., and T.S. Felid. 2000. Stem Hydraulic supply linked to leaf photosynthetic capacity: Evidence from
New Caledonian and Tasmanian rainforests. Plant, Cell \& Environment 23:1381.

Costa, S.C., M. Skinner, and B.L. Parker. 2004. HWA coldhardiness: Towards defining limits of range expansion. Proceedings, XV USDA Interagency research Forum on Gypsy Moth and Other Invasive Species. GTR-NE-332. 19-22.

Doccola, J.J., P. Castillo, and C. Taylor. 2002. Hemlock health and Hemlock woolly adelgid management in the urban forest. In proceedings, Hemlock woolly adelgid in Eastern United States Symposium. Feb. 2002. Rutgers University and New Jersey Agricultural Experiment Station in cooperation with the USDA Forest Service.

Doccola, J.J., P.M. Wild, I. Ramasamy, P. Castillo, and C. Taylor. 2003. Efficacy of Arborjet Viper microinjections in the management of hemlock woolly adelgid. Journal of Arboriculture 29:327-330.

Dujesiefken, D., W. Liese, W. Shortle, and R. Minocha. 2005. Response of beech and oak to wounds made at different times of the year. European Journal of Forest Research 124:113-117.

Grosman, D.M., W.W. Upton, F.A. McCook, and R.F. Billings. 2002. Systemic insecticide injections for control of cone and seed insects in Loblolly pine seed orchards-2 year results. Southern Journal of Applied Forestry 26: $146-152$.

Hudler, G.W., and S. Jensen-Tracy. 2002. Lac balsam ${ }^{\circledR}$ as a treatment to hasten wound closure and minimize discoloration and decay. Journal of Arboriculture 28:264-269.

Jenkins, J.J. 1994. Use of imidacloprid for aphid control on apples in Oregon: Potential for ground and surface water contamination. Department of Agricultural Chemistry. Oregon State University, Corvallis, OR.

Kozlowski, T.T., and C.H. Winget. 1963. Patterns of water movement in forest trees. Botanical Gazette 124:301-311.

Lancashire, J.R., and A.R. Ennos. 2002. Modeling the hydrodynamic resistance of bordered pits. Journal of Experimental Botany 53:1485-1493.

Larson, D.W., J. Doubt, and V. Mattes-Sears. 1994. Radially sectored hydraulic pathways in the xylem of Thuja occidentalis as revealed by the use of dyes. International Journal of Plant Sciences 155:569-582.

Martin, J.M., and T.D. Sydnor. 1987. Differences in wound closure rates in 12 tree species. HortScience 22:442-444.

Mayr, S., B. Rothart, and B. Damon. 2003. Hydraulic efficiency and safety of leader shoots and twigs in Norway spruce growing at the alpine timberline. Journal of Experimental Botany 54:2563-2568.

McClure, M.S. 1991. Density-dependent feedback and population cycles in Adelges tsugae (Homoptera: Adelgidae) on Tsuga canadensis. Environmental Entomology 20: 258-264. 
1998. Hemlock woolly adelgid, Adelges tsugae (Annand). The Connecticut Agricultural Experiment Station Fact Sheet.

McClure, M.S., S.M. Salom, and K.S. Shields. 1996. Hemlock Woolly Adelgid. Forest Health Technology Enterprise Team, USDA Forest Service, Morgantown, WV.

Neely, D. 1988. Tree wound closure. Journal of Arboriculture 14:148-152.

Oren, R., J.S. Sperry, G.G. Katul, D.E. Pataki, B.E. Ewers, N. Phillips, and K.V.R. Schäfer. 1999. Survey and synthesis of intra- and interspecific variation in stomatal sensitivity to vapour pressure deficit. Plant, Cell \& Environment 22: 1515-1526.

Pearce, R.B. 2000. Decay development and its restriction in trees. Journal of Arboriculture 26:1-11.

Potter, D.A., L. Foss, R.E. Baumler, and D.W. Held. 2002. Managing eastern tent caterpillars Malacosoma americanum $(\mathrm{F})$ on horse farms to reduce risk of mare reproductive loss syndrome. Preliminary results presented at the First Workshop on Mare Reproductive Loss Syndrome, University of Kentucky, Lexington, KY.

Rômulo, P.S. Jr., J.H. Smelt, J.J.T.I. Boesten, R.F.A. Hendriks, E.A. Sjoerd, and T.M. van der Zee. 2004. Preferential flow of bromide, bentazon, and imidacloprid in a Dutch clay soil. Journal of Environmental Quality 33: 1473-1486.

Sanchez-Zamora, M.A., and R. Fernandez-Escobar. 2004. Uptake and distribution of trunk injections in conifers. 2004. Journal of Arboriculture 30:73-79.

Schulze, E.-D., J. Ermák, M. Matyssek, M. Penka, R. Zimmermann, F. Vasícek, W. Gries, and J. Kuera. 1985. Canopy transpiration and water fluxes in the xylem of the trunk of Larix and Picea trees-a comparison of xylem flow, porometer and cuvette measurements. Oecologia 66: 475-483.

Shearer, B.L., C.E. Crane, and R.G. Fairman. 2004. Phosphite reduces disease extension of a Phytophthora cinnamomi front in Banksia woodland, even after fire. Australasian Plant Pathology 33:249-254.

Shigo, A.L. 1977. Compartmentalization of Decay in Trees. Agricultural Information Bulletin No. 405. USDA Forest Service.

- 1979. Tree Decay: An Expanded Concept. Agriculture Information Bulletin No. 419. USDA Forest Service.

- 1984. Compartmentalization: A conceptual framework for understanding how trees grow and defend themselves. Annual Review of Phytopathology 22:189-214.

— 1989. A New Tree Biology: Facts, Photos, and Philosophies on Trees and Their Problems and Proper Care. 2nd Ed. Shigo and Trees, Associates. Durham, NH. . 1991. Modern Arboriculture: A Systems Approach to the Care of Trees and Their Associates. Shigo and Trees, Associates. Durham, NH.
Tattar, T.A., J.A. Dotson, M.S. Ruizzo, and V.B. Bruce. 1998. Translocation of imidacloprid in three tree species when trunk and soil injected. Journal of Arboriculture 24:54-56.

Tattar, T.A., and S.J. Tattar. 1999. Evidence for the downward movement of materials injected into trees. Journal of Arboriculture 25:325-332.

Tyree, M.T., and F.W. Ewers. 1991. The hydraulic architecture of trees and other woody plants. The New Phytologist 119:345-360.

Ward, J.S., C.A.S.-J. Cheah, M.E. Montgomery, B.P. Onken, and R.S. Cowles. 2004. Eastern hemlock forests: Guidelines to minimize the impacts of hemlock woolly adelgid. USDA Forest Service, Northeastern Area State and Private Forestry.

Webb, R.E., J.R. Frank, and M.J. Raupp. 2003. Eastern hemlock recovery from hemlock woolly adelgid damage following imidacloprid therapy. Journal of Arboriculture 29: 298-302.

Young, L.C. 2002. The efficacy of micro-injected imidacloprid and oxydemeton-methyl on red gum eucalyptus trees (Eucalyptus camaldulensis) infested with red gum lerp psyllid (Glycaspis brimblecombei). Journal of Arboriculture 28:144-147.

Joseph J. Doccola (corresponding author)

Research and Development Director

Arborjet Inc.

99 Blueberry Hill Rd.

Woburn, MA, 01801, U.S.

joedoccola@arborjet.com

Eric J. Bristol

Research and Development Supervisor

Arborjet Inc.

99 Blueberry Hill Rd.

Woburn, MA, 01801, U.S.

Samantha D. Sifleet

Research and Development Associate

Arborjet Inc.

99 Blueberry Hill Rd.

Woburn, MA, 01801, U.S.

Joseph Lojko

Research and Development Associate

Arborjet Inc.

99 Blueberry Hill Rd.

Woburn, MA, 01801, U.S.

Peter M. Wild

Consulting Arborist

Arborjet Inc.

99 Blueberry Hill Rd.

Woburn, MA, 01801, U.S. 
Résumé. Le puceron lanigère de la pruche (Adelges tsugae) est un insecte piqueur-suceur introduit qui affecte les pruches (Tsuga spp.) en extrayant les hydrates de carbone des cellules parenchymateuses des rayons de xylème. Lorsque laissés non traités, les pucerons lanigères vont causer une réduction de croissance des pousses, un dépérissement progressif des branches et ultimement la mort de l'arbre. Dans cette étude, l'insecticide IMA-jet (5\% d'imidacloprid w/w) a été appliqué par micro-injection dans le tronc avec l'Arbojet Tree I.V. au moyen de la méthode VIPER. Seize pruches infestées par le puceron lanigère et choisies aléatoirement ont été traitées en 2002 et 2003 ainsi que huit autres arbres qui ont été sélectionnés comme témoin (non traités). Huit branches infestées par arbre ont été coupées comme échantillon chaque année (2003, 2004 et 2005) et évaluées. Quatre paramètres ont été utilisés pour évaluer l'efficacité et la durée des traitements. Ces derniers ont été le pourcentage de mortalité des pucerons lanigères, le nombre total ainsi que le nombre vivant de pucerons lanigères par centimètre linéaire de croissance de pousse, et la croissance annuelle de l'année courante. La pruche du Canada (Tsuga canadensis) dans cette étude subissait une pression initiale très forte par le puceron lanigère de la pruche. Au cours des trois années de cette étude, les faibles températures hivernales étaient insuffisantes pour causer une réduction appréciable ou soutenue des niveaux d'infestation. Sur les arbres témoins, les pucerons lanigères se sont accrus et la croissance des pruches a diminué. Le traitement par injection d'imidacloprid dans les tiges n'a pas permis d'obtenir une baisse marquée et rapide des pucerons lanigères; au contraire, cela requérait du temps (i.e. au moins un an). Durant l'année où les niveaux d'imidacloprid étaient encore efficaces, et ce suite au second traitement, nous avons observé des taux de mortalité suffisamment élevés chez les pucerons lanigères pour permettre une reprise de la croissance. Nous avons un haut degré de confiance qu'un traitement répétitif permet d'accroître les résultats. Nous recommandons un double dosage (ex.: pour les arbres de la classe 30 à $59 \mathrm{~cm}$, accroissement de la dose de $0,08 \mathrm{gm}$ d'ingrédient actif à 0,16 par centimètre de DHP) pour un degré d'efficacité accrû, pour accroître l'intervalle entre les traitements (de une fois par année vers une fois aux deux ans) et pour limiter le nombre de blessures qu'un arbre reçoit par centimètre de DHP/5. Les nouvelles recommandations de taux sont indiquées sur l'étiquette du IMA-jet amendée en 2006. Ces résultats démontrent que des pruches fortement stressées par le puceron lanigère de la pruche peuvent être traitées avec succès au moyen du système IMAjet et Arbojet Tree I.V.

Resumen. El adélgido lanígero (Adelges tsugae) (HWA) es un insecto chupador que afecta los abetos (Tsuga spp.) por la extracción de carbohidratos de las células del parénquima del xilema. Sin tratamiento, HWA resultó en crecimiento reducido de los brotes, muerte descendente de ramas y finalmente, la muerte del árbol. En este estudio, el insecticida IMA-jet (5\% imidacloprid w/w) fue aplicado por microinyección al tronco con el Arborjet Tree I.V. usando el método VIPER. Dieciséis abetos seleccionados aleatoriamente, infestados con HWA, fueron tratados en 2002 y 2003 y 8 árboles fueron seleccionados como no tratados (control). Ocho muestras de ramas infestadas por árbol fueron cortadas y evaluadas cada año (2003, 2004 y 2005). Se usaron cuatro parámetros para evaluar la eficacia y duración de los tratamientos. Estos fueron por ciento de mortalidad de HWA, HWA totales y vivos por $\mathrm{cm}$. lineal de crecimiento de brotes, y crecimiento corriente anual de los brotes. El abeto del este ( $T$. canadensis) en este estudio tuvo un incidencia alta inicial de HWA. En los tres años del estudio, las temperaturas bajas del invierno fueron insuficientes para causar una apreciable reducción de los niveles de infestación. En los controles, HWA incrementó y el crecimiento de los abetos disminuyó. Los tratamientos con imidacloprid inyectado al tronco no resultaron en una rápida reducción del HWA, tal vez requirieron más tiempo (al menos un año). En el año los niveles de imidacloprid en duración de eficacia, después del segundo tratamiento, observaron suficiente alta mortalidad de HWA para los abetos. Se tiene un alto grado de confidencia en que una repetición del tratamiento incremente lo observado. Se recomienda una dosis $2 \mathrm{x}$ (por ejemplo, para árboles en las clases de tamaño de 30-59 cm., incremento de 0.08 gm I.A. a 0.16 gm I.A./cm DAP) para un nivel de incremento de eficacia, para extender el intervalo de inyección (una vez cada dos años) y el límite del número de heridas que un árbol recibe a cm. DPA/5 (DAP/2). Las recomendaciones de nuevas tasas son presentadas en la etiqueta del IMA-jet en el 2006. Estos resultados demuestran que en los abetos con altas presiones de HWA pueden ser exitosamente tratados usando IMA-jet y el sistema Arborjet Tree I.V.

Zusammenfassung. Die Tsuga-Wollschildlaus (Adelges tsugae) (HWA) ist eine eingeführte saugende Insektenart, die Tsuga spp. befällt und Kohlenhydrate aus dem Xylem im Parenchym entzieht. Unbehandelt führt der HWA-Befall zu reduziertem Triebwachstum, Absterben der Äste und schließlich zum Baumsterben. In dieser Studie wurde das Insektizid IMA-jet (5 \% Imidacloprid w/w) durch eine Stamminjektion mit dem Arborjet Tree I.V. durch die ViperMethode appliziert. Sechzehn zufällig ausgewählte infizierte Tsugas wurden 2002 und 2003 behandelt und 8 Bäume wurden zu Kontrollbäumen bestimmt. Jedes Jahr (2002, 2003, 2004 und 2005) wurden pro infizierten Baum acht betroffene Äste geschnitten und untersucht. Es wurden vier Parameter benutzt, um die Effektivität und Dauer der Behandlung zu untersuchen. Diese waren die prozentuale Sterberate der Insekten, totale und lebende Insekten pro linearen $\mathrm{cm}$ des Triebwachstums, und der gegenwärtige Jahreszuwachs. Die Tsuga canadensis in dieser Studie hatte eingangs einen hohen Befalldruck. In den drei Jahren der Studie waren die Wintertemperaturen nicht tief genug, um eine bemerkenswerte oder nachhaltige Wirkung auf den Infektionsgrad zu zeigen. In den Kontrollen nahmen die Insekten zu und das Baumwachstum ab. Eine Behandlung mit dem Stamminjizierten Imidacloprid lieferte keine schnelle Abnahme der der Insekten und erforderte Zeit (mindestens 1 Jahr). In dem Jahr nach einer zweiten Behandlung mit Imidacloprid beobachteten wir eine zufrieden stellend hohe Sterblichkeit bei den Insekten und erwarteten neues Wachstum. Wir sind sehr zuversichtlich, dass eine wiederholte Behandlung die beobachteten Ergebnisse bestätigt. Wir empfehlen doppelte Dosierung (z.B. für Bäume in der Klasse mit 30-59 cm StU. Erhöhe von 0,8 gm A.I. auf 0,16 gm A.I./cm DBH) um die Wirksamkeit zu erhöhen, ausgedehnte Intervalle (einmal in zwei Jahren) und einer Begrenzung der Baumverletzung. Die neuen Dosierungsempfehlungen werden auf dem IMAjet Beipackzettel in 2006 gegeben. Diese Resultate demonstrieren, dass Tsugas mit hohem Insektenbefalldruck erfolgreich mit IMA-jet und dem Arborjet Tree I.V. behandelt werden können. 